\section{[15]鲜鋭なるX線摄影の 2.3の工夫}

弘前大学医学部 沢 田 正夫

（1）ホーカルプレンシタャッーの応用．蓄放式1000 $\mathrm{mA}$ 型の放射口に巾 $1 \mathrm{~cm}$ のスリットをもつ鉛板を取 付け此れをーカールプンンシャッターとした。本法の 露出時間は $1 / 50$ 秒以下となり, 乳幼児の胸部撮影飞応 用して好結果を得た。(2) ノースクリーンフィルムの 応用. イーストマンコダック会社のノースクリーンフ イルムを使用し，同時に $3 \mathrm{~mm}$ 径のピンホールを管球 に取付け撮影し鮮鋭なる像を得た，特に頭部では乳様 蜂窝の隔壁の状況资柱では椎体, 椎亏の辺縁は勿論, 骨の内部構造迄充分観察出来た。本法によると普通撮 影の約 4 倍程の露出を要するが，管球を強制水冷にし て身体各部の撮影が可能であった。

（第 9 回総会発表）

\section{〔16] X線写真の解像力に及ぼす諸因子について} 関東遇信病院 篗宮仙造

栗田 道・神田幸助

$\mathrm{X}$ 線写真の解像力に及ぼす諸因子即ち，(1)幾何学的 因子としての焦点の大きき，撮影距離，フィルム被写 体間距離. (2)写真的因子として増感紙, 螢光板, フィ ルム. (3) 運動的西子等を数值的に表現せんとし， 0.1 $\mathrm{mm}$ 巾より $0.8 \mathrm{~mm}$ 巾の金属線を並べだストチャ 一トをカセッテ上に密着 $5 \mathrm{~cm}, 10 \mathrm{~cm}, 15 \mathrm{~cm}, 20 \mathrm{~cm}$ の 高さに並べ，之を $80 \mathrm{~cm}, 120 \mathrm{~cm}, 150 \mathrm{~cm}$ の距離より 種々の増感紙を用い，或は焦点の大きさを変えて撮影 しその各々の解像力を数值的に読んだ。その結果増感 紙はフィルム面に近い部分に於てその影響は著明であ るが $20 \mathrm{~cm}$ 位離れるとその差は殆んぞなくなる。焦 点の大きさの影響はフィルム面に近い部分では勿論で あるが離れた部分に於ても大きくひびいてくる。

(第10回総会発表)

\section{〔17]鮮鋭な $\mathrm{X}$ 線像についての工夫}

日赤小松島病院 成田公正 花木 進 半田病院 松 原 茂一 牧野㰯療所 佐 藤大令 外国雑誈に記載された超小焦点による引伸直接撮影 像に刺戙され，增感紙，距離，特に管球焦点の影像に 及ぼす影響を検討し，ノーンスクリーン撮影について の実用化をこころみた結果を報告。

（第10回総会発表）
（18]実効焦点（1粍角，2粍角，5粍角，6粍角） 管球の鮮鋭に就いて

愛知県職員病院 大室埧二 彰断用 X線管に有って在来 $10 \mathrm{KW}$ 管球孝使用して いたが戦後蓄電器放電式装置が取り入れられ，蓄放電 用管球が製作され，又最近认は迴転陽極管の使用を見 るに至り，それぞれの管球の鮮鋭に就いての実験を発 表した。

（1）幾何学的に見た鮮鋭（半影数表）の差. (2)基礎実 験の撮影像の差. 其の他 $\mathrm{X}$ 線診断写真の対照について 報告.

（第10回総会発表）

\section{〔19〕胸部攝影に於ける管球焦点の再検討}

横浜医大 佐藤長三郎 三上康博・金子世紀

胸部レ写真は迴転陽極管の特殊な場合を除き一般に 阁定の $10 \mathrm{KW}$ が使用されているが鮮鋭の観点からは 出来れば 6 4 $4 \mathrm{KW}$ の固定焦点を使用したい。吾々は $\mathrm{X}$ 線管電圧を幾分高くし管電流少くして10KWの場 合と同し懪射時間で撮影して好結果を得ている。是れ 牥当り前のととであるが胸部撮影には $10 \mathrm{~kW}$ 前後の $\mathrm{X}$ 線管で適切であると云う従来の概念に対し参考迄に 報告する，更に近時胸部 X線撮影飞は漸次高圧低電流 の方向にむかって居るととからすれば廻転陽極管を使 用出来なくても， $4 \mathrm{KW}$ 前後の小焦点 $\mathrm{X}$ 線管でも充分 飞胸部撮影が出来ると考えられる。

（第10回総会発表）

〔20]レントゲン近接撮影に就て

北大医学部 龧 畑 幸 吉 軽度の肋骨々折や胸骨及び肋骨「カリエス」等普通 の「レントゲン」写真では患部の陰影が明瞭に「フィ ルム」に現れぬため，屡々診断が困難である。斯かる 場合には充分なる注意のもとにレントゲン近接撮影を 行うと予想外の好結果をるたらす事が屡々ある。其の 1.2 例を報告した。

（第 2 巻第 1 号掲載）

〔21]高電圧による遠距離撮影

徳島医専 岡橋 房一 大隅 盘

(第 3 回総会発表)

〔22〕電圧の營光板に及ぼす影響

徳島医大 岡 橋 房一 